\title{
Regulation of Flowering and Fruit Quality in Pineapple cv. Kew (Ananas comosus Merr.) Grown as Intercrops in Guava Orchard
}

\author{
B. R. Jana* \\ ${ }^{1}$ ICAR-RCER, Research Centre Ranchi, Jharkhand, India-834010 \\ ${ }^{2}$ ICAR-RCER, Research Centre for Makhana, Darbhanga, Bihar, India-846005 \\ *Corresponding author
}

\section{Ke y w o r d s \\ Pineapple, \\ Fertilizer, Mulching and ethephon, Yield and TSS \\ Article Info \\ Accepted: \\ 28 July 2020 \\ Available Online: \\ 10 August 2020}

\begin{abstract}
A B S T R A C T
A field trial was conducted to regulate flowering in pineapple cv. Kew by application of fertilizer, mulching and flowering hormone together to achieve maximum flowering and yield at ICAR-RCER, Ranchi Centre, India. The study was carried out infactorial RBD experimental design with three replications. All samples were analyzed through standard methods. Studies showed that in treatment $\mathrm{T}_{6}$ involving $\mathrm{F} 2$ fertilizer dose for pineapple (100 per cent $\mathrm{N}: \mathrm{P}: \mathrm{K}=600: 400: 400 \mathrm{~kg} / \mathrm{ha}$ ), plastic mulching and ethephon $30 \mathrm{ppm}$ together, the final flowering per cent of pineapple were 70.42 and 69.11 during first and second year. The pineapple cv. Kew recorded the maximum average TSS of $14.85^{\circ} \mathrm{B}$ under plastic mulch along with $\mathrm{F} 2$ fertilizer treatment in $\mathrm{T}_{6}$. The highest average yield of pineapple was observed in $\mathrm{F} 3$ ( $100 \%$ standard fertilizer dose of pineapple $+50 \%$ standard fertilizer dose of guava) and local weed mulching with ethephon $30 \mathrm{ppm}$ treatment $\left(\mathrm{T}_{8}\right)$ and average yield was $8.9 \mathrm{t} / \mathrm{ha}$ as intercrop $\left(\mathrm{TSS}=13.9^{\circ} \mathrm{B}\right.$ ). However, under $\mathrm{T}_{8}$ treatment, mulching material when changed from plastic to local weed, the average yield of both the years was increased from 7.95 to $8.9 \mathrm{t} / \mathrm{ha}$. On the contrary, the average TSS of the fruits decreased from $14.85^{\circ} \mathrm{B}$ to $13.9^{\circ} \mathrm{B}$. In $\mathrm{T}_{8}, \mathrm{~F} 3$ treatment with local weed mulching also recorded the maximum average soil moisture was $20.94 \%$ during growing period which influenced the production of bigger fruit $(1.41 \mathrm{~kg})$ by affecting growth process. Regulated deficient irrigation under hill and plateau condition of India gave the promising results which paved the way for cultivation of pineapple with $100 \%$ standard dose of $\mathrm{N}: \mathrm{P}: \mathrm{K}$ fertilizer (600:400:400 kg/ha). $\mathrm{T}_{6}$ treatment, i.e., $\mathrm{F} 2$ fertilizer dose, plastic mulching and ethephon $(30 \mathrm{ppm})$ may be recommended for obtaining quality fruit $\left(\mathrm{TSS}=14.85^{\circ} \mathrm{B}\right)$. On the other hand, $\mathrm{T}_{8}$, i.e., $\mathrm{F} 3$ fertilizer treatment, local weed mulching and ethephon (30 ppm) was appropriate for obtaining maximum yield $(8.9 \mathrm{t} / \mathrm{ha})$ as intercrop in guava orchard.
\end{abstract}

\section{Introduction}

The pineapple is one of the most edible fruit crops of the family Bromeliaceae which embraces about 2,000 species, mostly epiphytic and ornamental. It is known as
Ananas comosus Merr. (Morton 1987). The pineapple fruit has acquired few vernacular names like pinaby Spanish-speaking people, abacaxi in the Portuguese tongue, ananas by the Dutch and French and Asians (Paull and Duarte 2010, Elzibroek and Wind 2008). In 
China, it is po-lo-mah; sometimes in Jamaica, sweet pine; in Guatemala often merely "pine" (Bembry, 2017). It is believe to be originated in Southern Brazil and Paraguay stretching from Parana-Paraguay river banks (Morton 1987). In India the total pineapple production during 2017-18 is about 1705.76 thousand MT from 102.96 thousand ha (Hort. Stat, 2018). Overall pineapple production around the world was all time high about 27.4 million metric tons (Shahbandeh, 2019). Quality and economic value of pineapple fruits are determined by the flavonoids present in fruits, which influences color, aroma, and antioxidant composition and astringent properties (He and Giusti, 2010). Accumulation of flavonoids in fruits of pineapple was due to internal factor e.g., hormonal regulation and external factors, including temperature, humidity light conditions like number of sunny days during growth period, nutritional status of soil rhizosphere and biotic stresses (Koes et al., 2005; Jaakola and Hohtola, 2010; Azuma et al., 2012). In higher rainfall area of eastern India, pineapple is a common fruit and it is fair source of vitamins, carbohydrates, crude fiber, water and different minerals like $\mathrm{Ca}$, $\mathrm{Mg}$ and $\mathrm{Zn}$ (Kader et al., 2010) and minimal in fat and sodium content (Sabahelkhier et al., 2010). In main crop (up to 1 st harvest), the most economic rate of $\mathrm{N}_{2}$ application was 18 $\mathrm{g} \mathrm{N}_{2} /$ plant resulted in highest fruit weight and size which were of best quality fruits harvested from the plants and $40 \%$ of this dose was required for ratoon crop ( $\mathrm{Su}, 1969)$. Kew variety of pineapple grown as intercrop with mango orchard in laterite soil of West Bengal showed the need of more nitrogen for growth and development (Ghosh and Tarai, 2009). Hassan et al., (2008) also mentioned pineapple intercropped with jackfruit gave remarkable return in agro ecosystem of Madhupur district of Bangladesh. In Goa, India, it has been found that pineapple intercropping with cashew nut provides satisfactory income to the small and marginal farmer (Desai et al., 2010). Regulation of flowering in pineapple using ethrel has been reported by Avila et al., (2005) Cunha (2005). For synchronization of flowering and excellent yield, induction of flowering by chemical is gaining importance in recent times. It also facilitates the ease of harvesting and maintenance of uniform fruit quality in terms size and weight. For induction of flowering at a time in pineapple, several chemical have been reported to use. Ethrel/ethephon increases in protein and carbohydrates levels in bud and thereby enhances flowering (Avila et al., 2005). Organic mulches particularly mulching with sudan grass conserved more soil moisture which increased infiltration and enhanced yield in sesame agronomical crop (Teame et al., 2017). Commercial guava orchards are seen in the North eastern states like West Bengal, Jharkhand and Bihar, India (Maji and Das, 2013) and guava intercropped with pineapple is profitable crop combination in eastern and northeastern India. A study in this direction will provide an ample opportunity to the researchers to understand fruit growing and interaction study of soil, water and environment to pineapple plants. Therefore, an attempt has been made to induce profuse flowering and fruiting of pineapple growing as an intercrop with fruit crop like guava under rain-fed ecosystem of eastern plateau region of Jharkhand, India. Keeping above point in view, the present investigation was conducted to induce flowering in pineapple by different means such as application of fertilizer, mulching and flower inducing chemical to achieve the maximum yield and fruit quality.

\section{Materials and Methods}

The experiment was conducted at ICAR Research Complex for Eastern Region, Research Center, Ranchi, and Jharkhand, 
India. This area was situated $620 \mathrm{~m}$ above mean sea level (msl) and at $23025^{\prime} \mathrm{N}$ latitude and 850 20' East longitudes experiencing an average annual rainfall of $110-140 \mathrm{~cm}$. Here guava was cultivated under rain-fed ecosystem. Plot Size was $2 \mathrm{~m}$ x $5 \mathrm{~m}$ for pineapple bed while guava was planted in $5 \mathrm{~m}$ x $5 \mathrm{~m}$ distance. In pineapple bed pineapple spacing was $1 \mathrm{mx} 0.45 \mathrm{~m}$. Fertilizer dose of guava was 260:320:260 g / plant/year N:P:K (Mitra and Bose, 1985) while this was 600:400:600 kg/ha for pineapple tree (Roy et al., 1986). Statistical Design was Factorial RBD.

Treatments were in $\mathrm{F} 1=100 \%$ guava $(\mathrm{G})$ [i.e. no fertilizer dose for pineapple] only mulching of pineapple, F2 $=100 \%$ fertilizer dose of pineapple (P) [no fertilizer dose for guava], $\mathrm{F} 3=100 \%(\mathrm{P})+50 \%(\mathrm{G})$ [i.e. for pineapple dose was $100 \%$ but provision was such a that it (pineapple) may get additional moisture and soil nutrient from adjacent guava plots], $\mathrm{F} 4=50 \%(\mathrm{P})+50 \%(\mathrm{G})$ [i.e. for pineapple dose below 100\%]. Mulching materials were Paddy straw (M1), Local weed [M2 - mulching by Deenanath grass (Pennisetum pedicellatum Trin.) and green dried grass] and Plastic (M3). Total 12 treatment (4X3) combinations and control $\left(\mathrm{T}_{1}-\mathrm{T}_{13}\right)$ were developed for this study and replication was 3. Flowering induced hormone, ethephon, liquid was applied @ 20 ppm to half of the population of each replication and $30 \mathrm{ppm}$ to the rest. The treatment combinations were as follows.

\begin{tabular}{|c|c|c|c|}
\hline Treatments Combinations & M1 (Paddy straw) & M2 (Local weed) & M3 (Plastic) \\
\hline F1=100 \% guava (G) & $\mathbf{T}_{\mathbf{1}}=\mathrm{FIM} 1$ & $\mathbf{T}_{\mathbf{2}}=\mathrm{F} 1 \mathrm{M} 2$ & $\mathbf{T}_{\mathbf{3}}=\mathrm{F} 1 \mathrm{M} 3$ \\
\hline F2=100 \% fertilizer dose of pineapple $(\mathbf{P})$, & $\mathbf{T}_{\mathbf{4}}=\mathrm{F} 2 \mathrm{M} 1$ & $\mathbf{T}_{\mathbf{5}}=\mathrm{F} 2 \mathrm{M} 2$ & $\mathbf{T}_{\mathbf{6}}=\mathrm{F} 2 \mathrm{M} 3$ \\
\hline F3=100\% $(\mathbf{P})+\mathbf{5 0} \%(\mathbf{G})$ & $\mathbf{T}_{\mathbf{7}}=\mathrm{F} 3 \mathrm{M} 1$ & $\mathbf{T}_{\mathbf{8}}=\mathrm{F} 3 \mathrm{M} 2$ & $\mathbf{T}_{\mathbf{9}}=\mathrm{F} 3 \mathrm{M} 3$ \\
\hline F4=50 \% (P) +50\% $(\mathbf{G})$ & $\mathbf{T}_{\mathbf{1 0}}=\mathrm{F} 4 \mathrm{M} 1$ & $\mathbf{T}_{\mathbf{1 1}}=\mathrm{F} 4 \mathrm{M} 2$ & $\mathbf{T}_{\mathbf{1 2}}=\mathrm{M} 4 \mathrm{M} 3$ \\
\hline Control: No fert., mulching \&ethephon & & $\mathbf{T}_{\mathbf{1 3}}=$ Control & \\
\hline
\end{tabular}

*Half of the pineapple population of each replicated plot was treated with $20 \mathrm{ppm}$ and $30 \mathrm{ppm}$ ethephon equally

Ethephon was applied in first week of January. No irrigation was provided except lifesaving irrigation of 1 or 2 spells given during May-June at one month interval to establish young orchard at their initial establishment as well as mature plants for flowering and fruiting.

The climate was sub-humid and subtropical type. High humidity $(78.14 \%-84.14 \%)$ and low evaporation rate were experienced after June and continues up to onset of winter (Singh, 1999). Soil was acidic and $\mathrm{pH}$ ranged from 5.0-6.5, which was ideal for pineapple and guava cultivation. TSS was measured by hand held re-fractrometer and expressed as degree brix ( $\left.{ }^{0} \mathrm{~B}\right)$ (Ranganna, 1977). Soil moisture was recorded from the sample taken at soil depth of $15 \mathrm{~cm}$ through standard method (TNAU-2013) in every month.

\section{Results and Discussion}

Data pertaining to Fig-1 revealed that in $\mathrm{T}_{6}$, F2 fertilizer and plastic mulching, initial flowering percentage was 48.61 per cent while it was reported to be 70.42 per cent at final flowering stage in case of $30 \mathrm{ppm}$ ethephon (application before flowering in January in first year). A close perusal of the Fig-2, expressed that in the same treatment, $\mathrm{T}_{6}, \mathrm{~F} 2$ fertilizer and plastic mulching initial flowering percentage was 39.82 and final flowering was 69.11 in case of $30 \mathrm{ppm}$ ethephon application in second year. However in case of yield, the average highest yield (8.9 
t/ha) was observed in pineapple in local weed mulching with $\mathrm{F} 3$ fertilizers and $30 \mathrm{ppm}$ ethephon application $\left(\mathrm{T}_{8}\right)$. Local weed mulching conserve more soil moisture because of increased infiltration, optimum aeration and imparting organic matter to soil resulted in congenial rhizosphere and the maximum production of pineapple. Mulching material with high nitrogen content improves soil nitrogen status which finally increase the crop yield (Telkar et al., 2017). In T8, combination of $\mathrm{F} 3$ fertilizer dose and local weed mulching treatment, pineapple plot may obtain additional soil moisture and nutrients from adjacent guava plotto boost production. These findings were corroborated by the findings of Teame et al., (2017) while working on sesame crop with Sudan grass mulching. Local weed decomposed faster than paddy straw and plastic mulching. This could help in increasing water holding capacity of the soil and proving organic matter and nutrient to the soil (Ngosong et al., 2018 and Ranjan et al., 2017). In T8, F3-local weed mulching and ethephon $30 \mathrm{ppm}$ treatment, the average TSS of the fruit was $13.9^{0} \mathrm{~B}$. Under same treatment when mulching material was changed from plastic to local weed, average yield was increased from 7.95 t/ha to $8.9 \mathrm{t} / \mathrm{ha}$ but the average TSS of the crop was decreased from $14.85^{\circ} \mathrm{B}$ to $13.9^{0} \mathrm{~B}$. Regulated deficient irrigation under hill and plateau condition of India also gave the promising results for average quality fruit $\left(\mathrm{TSS}=14.85^{\circ} \mathrm{B}\right)$, when pineapple was cultivated with standard $\mathrm{N}: \mathrm{P}: \mathrm{K}$ fertilizer (600:400:400 kg/ha) along with plastic mulching and ethephon (30 ppm) but yield was lower. A close look on the Fig-3 revealed that local weed mulching (M2) with F3 fertilization treatment $\left(\mathrm{T}_{8}\right)$ increased fruit weight due to sufficient availability of moisture and organic matter to plant under harsh condition.

Table.1 Pooled data on flowering, fruit weight and yield, as affected by different treatments with $30 \mathrm{ppm}$ ethephon (best)

\begin{tabular}{|c|c|c|c|c|}
\hline Treatments & $\begin{array}{c}\text { Average } \\
\text { Flowering } \\
(\%)\end{array}$ & $\begin{array}{l}\text { Average Fruit } \\
\text { Weight } \\
\text { (Kg) }\end{array}$ & $\begin{array}{l}\text { Average } \\
\text { Yield } \\
\text { (t/ha) }\end{array}$ & $\begin{array}{c}\text { TSS of fruit } \\
\left({ }^{\mathbf{0}} \mathrm{B}\right)\end{array}$ \\
\hline$T_{1}=F 1, M 1$ and 30 ppm Ethephon & 51.07 & 0.93 & 5.12 & 11.65 \\
\hline$T_{2}=$ F1, M2and 30 ppm Ethephon & 46.90 & 1.06 & 7.00 & 11.85 \\
\hline$T_{3}=F 1, M 3$ and 30 ppm Ethephon & 61.69 & 0.99 & 5.30 & 12.55 \\
\hline $\mathrm{T}_{4}=\mathrm{F} 2, \mathrm{M} 1$ and $30 \mathrm{ppm}$ Ethephon & 46.82 & 1.17 & 6.79 & 12.15 \\
\hline$T_{5}=\mathrm{F} 2, \mathrm{M} 2$ and 30 ppm Ethephon & 54.49 & 1.39 & 8.16 & 12.35 \\
\hline$T_{6}=F 2, M 3$ and 30 ppm Ethephon & 69.76 & 1.23 & 7.33 & 12.75 \\
\hline$T_{7}=$ F3, M1 and 30 ppm Ethephon & 57.64 & 1.24 & 8.16 & 12.60 \\
\hline$T_{8}=F 3, M 2$ and 30 ppm Ethephon & 62.44 & 1.41 & 8.90 & 13.90 \\
\hline$T_{9}=$ F3, M3 and 30 ppm Ethephon & 58.77 & 1.24 & 7.95 & 14.85 \\
\hline$T_{10}=$ F4, M1and 30 ppm Ethephon & 43.89 & 0.99 & 5.76 & 11.25 \\
\hline $\mathrm{T}_{11}=\mathrm{F} 4, \mathrm{M} 2$ and $30 \mathrm{ppm}$ Ethephon & 51.05 & 1.15 & 5.01 & 11.55 \\
\hline$T_{12}=F 4, M 3$ and 30 ppm Ethephon & 54.27 & 1.06 & 5.56 & 12.53 \\
\hline $\begin{array}{c}T_{13}=\text { Control: no } \\
\text { fert,muching\&Ethephon }\end{array}$ & 24.71 & 0.89 & 3.2 & 11.05 \\
\hline
\end{tabular}

*Treatment means were significant at $\mathrm{p}<0.05 \%$ 
Plate.1 Pineapple as intercrop in guava orchards at ICAR-RCER, Ranchi, Jharkhand

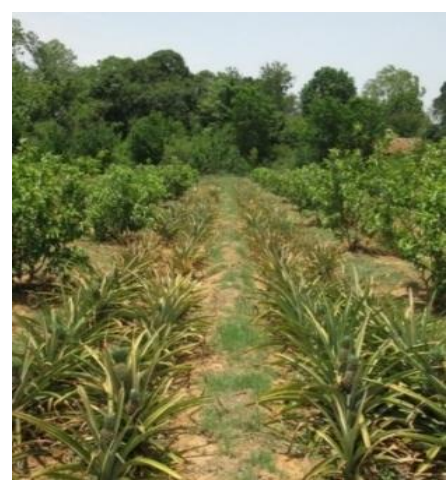

Plate.2 Synchronization of pineapple flowering with $30 \mathrm{ppm}$ ethephon and plastic mulching and $100 \%$ standard dose of fertilizer (N: P: K 600:400:400kg/ha). The maximum average flowering was $70.42 \%$

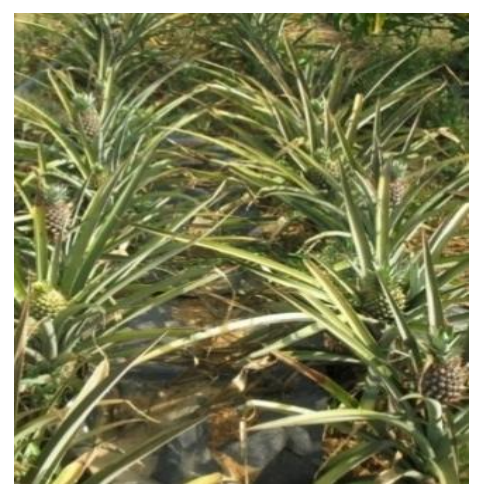

Fig.1 Synchronization of flowering in pineapple by application ethephon $20 \mathrm{ppm}$ and $30 \mathrm{ppm}$ during first year

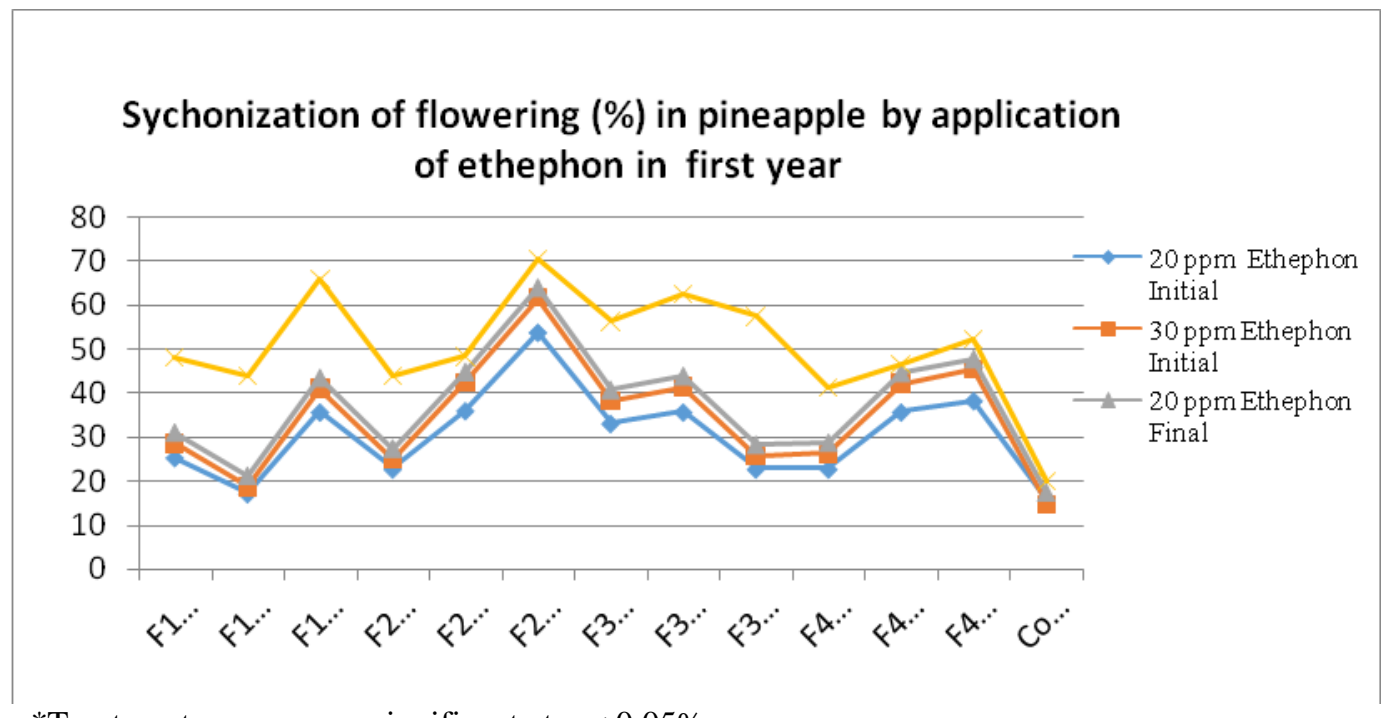

*Treatment means were significant at $\mathrm{p}<0.05 \%$ 
Fig.2 Synchronization of flowering in pineapple by application of ethephon $20 \mathrm{ppm}$ and $30 \mathrm{ppm}$ during second year

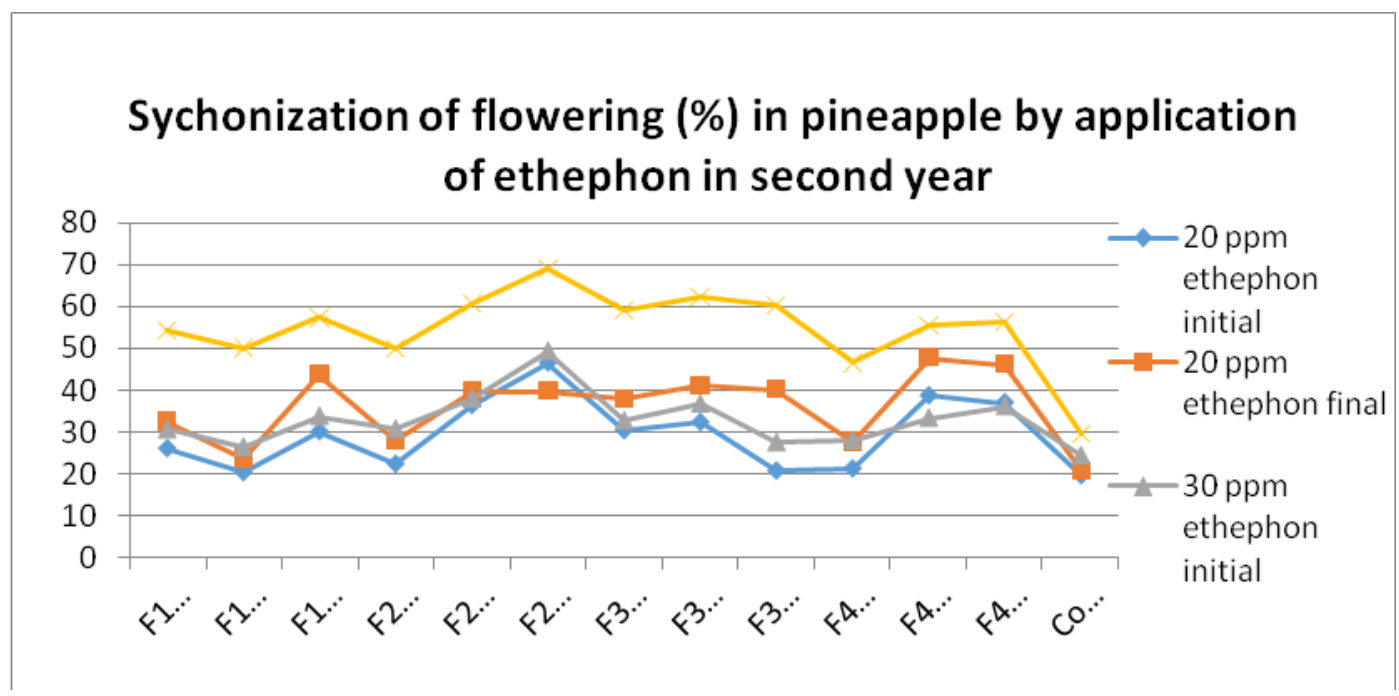

*Treatment means were significant at $\mathrm{p}<0.05 \%$

Fig.3 Relation between moisture and flowering in pineapple induced by fertilizer, mulching and 30 ppm ethephon (best)

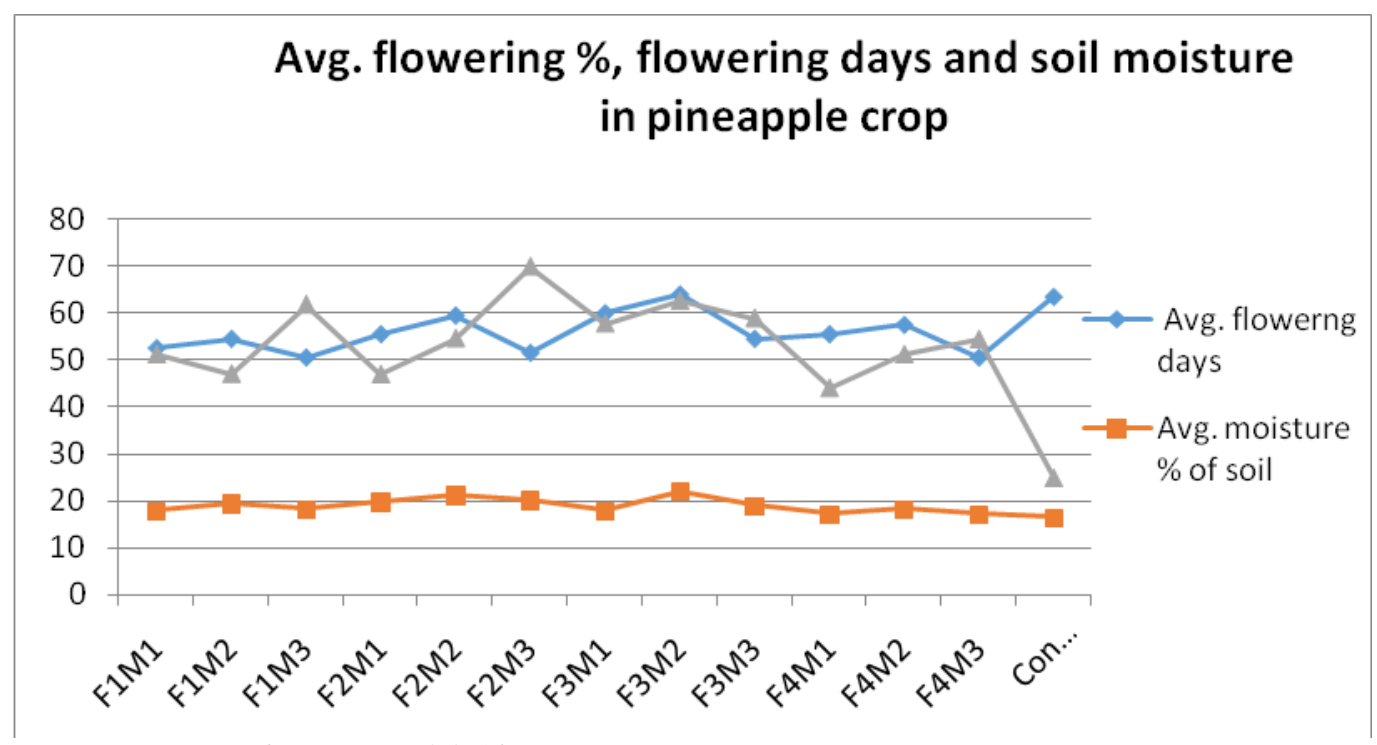

*Treatment means were significant at $p<0.05 \%$

In above case, it was also found that the maximum average soil moisture of $20.94 \%$ during growth period which influenced for bigger fruit size $(1.41 \mathrm{~kg})$ by influencing growth and developmental process. This results was also supported by Singleton, 1965, Joy et al., 2010 and Priya Devi et al., 2013; where fruit weight was influenced by sunlight and soil moisture. But in $\mathrm{T}_{6}, \mathrm{M} 3$ plastic mulching, fruit weight diminished because of flowering was the maximum which competes for available nutrients from soils in unfavorable weather condition. Fertilizer and moisture stress influence more flowering in 
presence of ethephon $30 \mathrm{ppm}$ but nourishment for fruit were interrupted and slow. High temperature during June paved the way for faster ripening of pineapple fruits early. From two consecutive years of study, it was observed that in $\mathrm{T}_{6}$ plastic mulching of $\mathrm{F} 2$ induced early flowering and just took 54 days and 51 days from first January of the respective years. Plastic mulching increased soil temperature which promote osmoregulation, resulted in increased and early flowering but the fruit size was decreased. In T8, local weed mulching ensured optimum average flowering (62.44\% in F3M2) (Table1) and gave average maximum production. This might be due to getting additional soil moisture and nutrient from adjacent guava plot/plants. On the contrary, in plastic mulching (F2M3) of $\mathrm{T}_{6}$, the maximum average flowering was $(69.76 \%)$ but recorded less yield due to moisture and nutrient stress. Yakushiji et al., (1996) also reported that moisture stress affects many physiological process including sugar accumulation in citrus trees. Mulching also influenced early flowering in cucumber by increasing soil temperature (Shaik and Fouda, 2008). In previous study related to plastic mulching in strawberry also paved the way for early flowering (Das et al., 2007). In our study, in $\mathrm{T}_{8}$ application of $30 \mathrm{ppm}$ ethephon influenced fruit weight and fruit quality through standard fertilizer dose and local weed mulching. This result was supported by Joy et al., 2010 and Pal et al., 2015 when they applied growth regulators and mulching material for pineapple production.

Conclusion of the study is as follows:

In spite of having medium flowering per cent, the maximum average yield of pineapple 8.9 t/ha was obtained in treatment in $\mathrm{T}_{8}$, where $\mathrm{F} 3$ $[100 \%$ recommended dose $(\mathrm{P})+50 \%(\mathrm{G})]$ and local weed mulching along with the application of ethephon @ 30 ppm were applied. This was due to bigger fruit size as fruits were supported by sufficient nutrients and soil moisture.

\section{Acknowledgement}

Authors are thankful to Director ICAR-RCER for technical guidance.

\section{References}

Azuma, A., H.Yakushiji, Y.Koshita and S. Kobayashi. 2012. Flavonoid biosynthesis-related genes in grape skin are differentially regulated by temperature and light conditions. Planta. 236, 1067-1080. doi: 10.1007/s00425-012-1650-x.

Avila M, M.A .Blanco, N. Nievesand J.G. Olmedo. 2005. Effects of ethrel on flowering induction in pineapple Ananas comosus (L) Merr. Smooth Cayenne cv. Serrana 1, Changes in levels of polyamines, proteins and carbohydrates. Acta Horticulture. 666, 175-182.

Bembry, R.R. 2017. Interesting facts about pineapple plants Annanus comosus: Pineapple Ananus comosus botanical name of the edible bromeliace plant, $\mathrm{P}$ $1-3$,

https://www.heartandflowerbox.com/pi neapple-ananas-comosus/

Cunha, G.A.P. 2005. Applied aspects of pineapple flowering. Bragantia 64(4) http://dx.doi/10.1590/s000687052005000400001.

Das, B. V.Nath, B.R.Jana, P.Dey, K.K. Pramanik and D.K. Kishore. 2007. Performance of strawberry cultivars grown on different mulching materials under sub-humid subtropical plateau conditions of Eastern India. Indian Journal of Horticulture. 64(2), 136-143.

Desai, A.R., D.G. Dhandar, Babu. Leebu and R.B.Dalvi. 2000. Classificatory analysis of some cashew germplasm 
accessions of Goa. PLACROSYM XIV, Hyderabad, 12-15 December, 2000.

Elzebroek, T. and K. Wind. 2008. Guide to cultivated plants. Vii-Xi +516 pp. CABI, Wallingford, U.K. DOI : 10.1079/9781845933562.0000.

Ghosh, S.N. and R.K. Tarai. 2009. Influence of nitrogen levels on pineapple grown as intercrop in laterite soil. Indian Journal of Fertilizer. 5(8), 27-28.

Hassan, M.K., M. M. Ahmed and M. G. Miah. 2008. Agro-economic performance of Jackfruit-pineapple agro-forestry system in Madhupur. Journal of Agriculture and Rural Development. 6(1\&2), 147-156.

He, J. and M.Giusti. 2010. Anthocyanins: natural colorants with health-promoting properties. Annual Review Food Science and Technology. 1, 163-187 doi:

10.1146/annurev.food.080708.100754.

Hort. Statistics. 2018. Horticultural Statistics at a Glance 2018 , Horticulture Statistics Division, Department of Agriculture, Co-operation \& Farmers Welfare, Government of India, New Delhi.

Jaakola, L., M. Poole, M.O. Jones, T. Kämäräinen-Karppinen, J.J. Koskimäki, A. Hohtola. 2010. A Squamosa box gene involved in the regulation of anthocyanin accumulation in bilberry fruits. Plant Physiology 153: 16191629 doi: $10.1104 / p p .110 .158279$.

Joy, P.P. 2010. Production technology for Pineapple Variety Kew. KAU.

Kader. A., F.Mah, J. Hossain, M. Moniul, I.G.Kabir, S.K. Sarkar and Abasar, N. 2010. A Comparative analysis on the nutritional contents of two varieties of pineapple of Chittagong region. The Chittagong University Journal of Biological Sciences. 5(1 \&2), 105-112.

Koes, R., W. Verweij and F.Quattrocchio.
2005. Flavonoids: a colorful model for the regulation and evolution of biochemical pathways.Trends in Plant Sciences. 10, 236-242. doi: 10.1016/j.tplants.2005.03.002.

Maji, S. and B.C. Das. 2013. Intercropping in young guava orchard. Annals of Horticulture. 6(1), 93-98.

Mitra, S.K. and T.K. Bose.1985 Standardization of fertilizer dose of Pineapple under alluvial plains of West Bengal. South Indian Horticulture.33, 286-292.

Morton, J. 1987. Pineapple. In: Fruits of warm climates. p. 18-28. Julia F. Morton, Miami, FL.

Ngosong, C., J.N. Okolle and A.S. Tening. 2018. Mulching: A Sustainable Option to Improve Soil Health. In Panpatte DG, Jhala YK, (eds.) Soil fertility management and sustainable development, Buea, Cameroon, P 231249. DOI: $10.1007 / 978-981-13-5904-$ $0 \_11$.

Pal, R., S. K.Mahato, Binoy, Chhetri. and C. P. Suresh. 2015. Growth regulators influencing yield and quality of pineapple [Ananus comosus (L) Merr.]. Ecology, Environment and Conservation Paper. 21(2), 885-890

Paull, R.E. and O. Duarte. 2012. Tropical Fruits Volume 2, 2nd edn. CAB International, Wallingford, pp. 1-371.

Priya-Devi, S., M. Thangam, M. S. Ladaniya and N. P. Singh. 2013. Pineapple-a profitable fruit crop for Goa Pineapplea profitable fruit crop for Goa. Technical Bulletin No.: 35, ICAR (RC), Goa.

Ranganna, S. 1977. Manual of analysis of fruits and vegetables product. Tata McGraw-Hill Publishing Co. Ltd. New Delhi. Pp 29-31.

Ranjan, P., G.T.Patle, M.Prem and K.R. Solanke. 2017. Organic mulching. A water saving technique to increase the 
production of fruits and vegetables. Current Agriculture Research Journal.https//dx.doi.org/10.12944/CA RJ.5.3.17.

Roy, R., M. Hossain, S.K. Mitra. And T.K. Bose. 1986. Fertilization in pineapple. Maharastra. Journal of Horticulture. 3, 38-43.

Sabahelkhier, K.M., A.S. Hussain. And K.E.A. Ishag. 2010. Effect of maturity stage on protein fractionation, in vitro protein digestibility and anti-nutrition factors in pineapple (Ananas comosus) fruit grown in southern Sudan. African. Journal of Food Sciences, 4(8), 550 552.

Shahbandeh, M. 2019. Global Pineapple production by leading countries 2017, Agriculture: Statistica: Aug 9, 2019.

Shaikh, A.E. and T. Fouda. 2008. Biological Engineering effects of different mulching types on soil temperature and cucumber production under Libyan condition. Misr Journal of Agriculture Engineering. 25(1), 160- 175.

Singh, H.P. 1999. Horticulture development in tribal areas. Proceedings of National Seminar on Sustainable Horticultural Production in Tribal Regions, July 2526., pp 5-18.

Singleton, V.L. 1965. Chemical and Physical Development of the Pineapple Fruit I.
Weight per Fruitlet and Other Physical Attributes. Journal of Food Science. https://doi.org/10.1111/j.13652621.1965.tb00270.x

$\mathrm{Su}$, N.R. 1969. Recommendations on the nutritional management, of pineapple in Taiwan. Potash Rev., Subject 27, 48th Suite. p. 1-8.

Teame, G., A. Tsegayand B.Abrha. 2017. Effect of organic mulching on soil moisture, yield and yield contributing components of sesame (Sesemum indicum L.). International Journal of Agronomy. https://doi.org/101155/2017 4767509.

Telkar, S.K., K. Kant and S.P.S. Solanki. 2017. Effect of mulching on soil moisture conservation. Biomolecule Report. BR/09/17/02.

T.N.A.U. 2013. TNAU Agritech Portal. Agriculture: Resource Management: Soil sampling procedures. http://agritech.tnau.ac.in/agriculture/agr i_soil_sampling.html.

Yakushiji, H., H.Nonami, T. Fukuyama, S. Ono, N.Takaji. And Hasimoto, Y. 1996. Sugar accumulation enhanced by osmoregulation in satsuma mandarin fruits. Journal of American Society of Horticultural Sciences. 121, 466-472.

\section{How to cite this article:}

Jana, B. R. 2020. Regulation of Flowering and Fruit Quality in Pineapple cv. Kew (Ananas comosus Merr.) Grown as Intercrops in Guava Orchard. Int.J.Curr.Microbiol.App.Sci. 9(08): 3827-3835. doi: https://doi.org/10.20546/ijcmas.2020.908.441 